\title{
Pengaruh Loyalitas Terhadap Kinerja Guru SD Awal
}

\author{
Suwardi ${ }^{1}$, Masni Erika Firmiana ${ }^{2}$, Fitrin $\mathrm{Nida}^{3}$ \\ ${ }^{1,3}$ Program Studi Pendidikan AUD, ${ }^{2}$ Program Studi Jurusan Psikologi, Fakultas Psikologi dan Pendidikan, \\ Universitas Al Azhar Indonesia, Jalan Sisingamangaraja Kebayoran Baru, Jakarta, 12110 \\ Penulis untuk Korespondensi/E-mail: suwardi@uai.ac.id
}

\begin{abstract}
Abstrak- Sekolah memeliki peran penting dalam suksesnya tujuan pendidikan nasional. Komponen di sekolah berkontribusi secara aktif dalam keberhasilan proses pendidikan di sekolah, termasuk guru sebagai pengajar dan pendidik. Guru hendaknya memiliki loyalitas kerja dalam mendidik di sekolah, karena dengan loyalitas yang tinggi maka kinerja guru akan menjadi baik yang berdampak pada peningkatan kualitas mengajar. Namun pada saat sekarang banyak guru yang kurang memiliki loyalitas kerja. Berdasarkan hasil tersebut perlu diteliti dan ditelaah pengaruh loyalitas guru-guru sekolah dasar (SD) di bawah Yayasan Pesantren Islam Al Azhar. Metode penelitian yang digunakan adalah deskriptif kuantitatif dengan pengisian kuesioner oleh sejumlah sampel sebanyak 42 guru dari total 140 guru dengan teknik sampling acak sederhana. Dari hasil penelitian diperoleh kesimpulan bahwa loyalitas guru berpengaruh terhadap kinerja guru yang ditandai dengan perolehan koefisien determinasi $\left(r_{y}^{2}\right)$ sebesar = 0,932 yang berarti bahwa 93,2\% loyalitas guru $(X)$ berpengaruh terhadap kinerja guru dan $6,8 \%$ ditentukan oleh faktor lain. Hasil analisis menunjukkan nilai $t$ hitung $=0,349$ selanjutnya diperoleh nilai $t_{\text {tabel }}$ untuk signifikansi $5 \%$ diperoleh nilai $t$ tabel $=1,64$. Hasil $t_{\text {hitung }}$ sebesar 0,349 lebih kecil dari $t_{\text {tabel }}=1,64$ sehingga $H_{1}$ ditolak dan $H_{0}$ diterima. Hal ini berarti variabel loyalitas guru berpengaruh tidak signifikan terhadap kinerja guru.
\end{abstract}

Kata Kunci: loyalitas kerja, kinerja guru, SD awal

Abstract - Schools have an important role in the success of the national education goals. Components in schools contribute actively to the success of the educational process in schools, including teacher as a teacher and educator. Teachers should have the loyalty of work in educating in schools, because of the high loyalty then the performance will be good teachers that have an impact on improving the quality of teaching. However, at the present time many teachers who lack job loyalty. Based on these results need to be researched and studied the influence of loyalty elementary school teachers below the Al Azhar Islamic Pesantren Foundation. The method used is descriptive quantitative questionnaire by a sample of 42 teachers from a total of 140 teachers with simple random sampling technique. From the research we concluded that the loyalty of teachers affect the performance of teachers who are marked by the acquisition of the coefficient of determination $\left(r^{2} y\right)$ amounting $=0.932$ which means that $93.2 \%$ of teachers loyalty $(X)$ effect on the performance of teachers and $6.8 \%$ is determined by other factors. The analysis showed the value of $t=0.349 t_{\text {tabel }}$ values obtained subsequent to the $5 \%$ significance values obtained $t_{\text {table }}=1.64$. Results $t_{\text {hitung }} 0,349$ less than the table $=1,64$ so that $\mathrm{HO}$ rejected and $\mathrm{H1}$ accepted. This means the teacher loyalty variables not significant effect on teachers' performances.

Keywords: Loyalty Work, Performance of Teacher, Early Primary School

\section{PENDAHULUAN}

Latar Belakang Masalah

М $\begin{aligned} & \text { emasuki abad } 21 \text { secara internal masyarakat } \\ & \text { Indonesia berada dalam tatanan kehidupan }\end{aligned}$ yang cukup kritis di berbagai bidang, baik ekonomi, politik, sosial budaya termasuk juga bidang pendidikan. Kualitas dan mutu pendidikan di Indonesia masih sangat memprihatinkan. Hal ini nampak pada rendahnya prestasi belajar akademik, 
daya kreatifitas dan juga sikap kemandirian siswa. Di sisi lain, kehidupan dunia global telah memaksa masyarakat Indonesia untuk bersaing secara ketat dengan berbagai kemajuan dibidang sains dan teknologi.

Kemajuan ilmu pengetahuan dan teknologi (IPTEK) tidaklah terlepas dari perubahan yang ada dalam pendidikan karena pendidikan merupakan salah satu wahana untuk meningkatkan sumber daya manusia. Untuk itu pemerintah selalu berusaha meningkatkan kualitas dan kuantitas pendidikan. Untuk mencapai keberhasilan dalam dunia pendidikan, maka keterpaduan antara kegiatan guru dengan kegiatan siswa sangat diperlukan. Oleh karena itu guru diharapkan mampu mengatur, mengarahkan dan menciptakan suasana yang mampu memotivasi siswa untuk belajar. Karena guru merupakan kunci dalam peningkatan mutu pendidikan.

Loyalitas kerja guru terhadap pekerjaan merupakan keyakinan seorang guru mengenai pekerjaan yang diembannya, yang disertai adanya perasaan tertentu, dan memberikan dasar kepada guru tersebut untuk membuat respons atau berperilaku dalam cara tertentu sesuai pilihannya. Loyalitas kerja guru terhadap pekerjaan mempengaruhi tindakan guru tersebut dalam menjalankan aktivitas kerjanya. Bilamana seorang guru memiliki loyalitas kerja yang tinggi terhadap pekerjaannya, maka sudah barang tentu guru akan menjalankan fungsi dan kedudukannya sebagai tenaga pengajar dan pendidik di sekolah dengan penuh rasa tanggung jawab. Demikian pula sebaliknya seorang guru yang memiliki loyalitas tinggi terhadap pekerjaannya, pastilah dia hanya menjalankan fungsi dan kedudukannya sebatas rutinitas belaka. Untuk itu amatlah perlu kiranya dibentuk loyalitas guru yang tinggi terhadap pekerjaan, mengingat peran guru dalam lingkungan pendidikan dalam hal ini sekolah amatlah sentral.

Loyalitas kerja guru terhadap pekerjaan dapat dilihat dalam bentuk kesetiaan, komitmen dan kepuasaannya terhadap pekerjaan maupun dalam bentuk motivasi kerja yang ditampilkan. Guru yang memiliki loyalitas tinggi terhadap pekerjaan, sudah barang tentu akan menampilkan persepsi dan kepuasan yang baik terhadap pekerjaanya maupun motivasi kerja yang tinggi, yang pada akhirnya akan mencerminkan seorang guru yang mampu bekerja secara profesional dan memiliki kompetensi profesional yang tinggi.
Loyalitas kerja yang tinggi maupun rendah seorang guru terhadap pekerjaan tergantung dari guru bersangkutan maupun kondisi lingkungan. Menurut Walgito, loyalitas yang ada pada diri seseorang dipengaruhi oleh faktor internal, yaitu faktor fisiologis dan psikologis, serta faktor eksternal, yaitu berupa situasi yang dihadapi individu, norma-norma, dan berbagai hambatan maupun dorongan yang ada dalam masyarakat.

Sekolah sebagai organisasi, di dalamnya terhimpun unsur-unsur yang masing-masing baik secara perseorangan maupun kelompok melakukan komunikasi interpersonal untuk mencapai tujuan. Unsur-unsur yang dimaksud, tidak lain adalah sumber daya manusia yang terdiri dari kepala sekolah, guru-guru, staf, peserta didik atau siswa, dan orang tua siswa. Tanpa mengenyampingkan peran dari unsur-unsur lain dari organisasi sekolah, kepala sekolah dan guru merupakan personil intern yang sangat berperan penting dalam menentukan keberhasilan pendidikan di sekolah.

Perubahan paradigma pendidikan merupakan respon terhadap perkembangan tuntutan global sebagai suatu upaya untuk mengadaptasikan sistem pendidikan yang mampu mengembangkan sumber daya manusia untuk memenuhi tuntutan zaman yang sedang berkembang. Melalui reformasi pendidikan, pendidikan harus berwawasan masa depan yang memberikan jaminan bagi perwujudan hak-hak azasi manusia untuk mengembangkan seluruh potensi dan prestasinya secara optimal guna kesejahteraan hidup di masa depan.

Guru adalah salah satu unsur manusia dalam proses pendidikan. Dalam proses pendidikan di sekolah, guru memegang tugas ganda yaitu sebagai pengajar dan pendidik. Sebagai pengajar guru bertugas menuangkan sejumlah bahan pelajaran ke dalam otak anak didik, sedangkan sebagai pendidik guru bertugas membimbing dan membina anak didik agar menjadi manusia susila yang cakap, aktif, kreatif, dan mandiri. Djamarah berpendapat bahwa baik mengajar maupun mendidik merupakan tugas dan tanggung jawab guru sebagai tenaga profesional. Oleh sebab itu, tugas yang berat dari seorang guru ini pada dasarnya hanya dapat dilaksanakan oleh guru yang memiliki kompetensi profesional yang tinggi.

Guru memegang peranan sentral dalam proses belajar mengajar, untuk itu mutu pendidikan di suatu sekolah sangat ditentukan oleh kemampuan 
yang dimiliki seorang guru dalam menjalankan tugasnya. Menurut Aqib guru adalah faktor penentu bagi keberhasilan pendidikan di sekolah, karena guru merupakan sentral serta sumber kegiatan belajar mengajar. Lebih lanjut dinyatakan bahwa guru merupakan komponen yang berpengaruh dalam peningkatan mutu pendidikan di sekolah. Hal ini menunjukkan bahwa kemampuan atau kompetensi profesional dari seorang guru sangat menentukan mutu pendidikan. Ditinjau dari segi loyalitas guru, pada saat sekarang ini banyak guru yang tidak mengerti makna mendidik yang kenyataannya kesadaran untuk memajukan satuan pendidikan tidak berjalan semestinya, contohnya seperti tidak adanya disiplin waktu dan ketidaksetiaan dalam menjalankan tugasnya. Guru sekarang hanya menjalankan tugasnya hanya sebatas untuk menggugurkan kewajibannya, tanpa adanya komitmen penuh untuk mendidik siswa secara utuh dan menyeluruh baik jasmani maupun rohani. Karena kurangnya rasa memiliki terhadap tingkat satuan pendidikan, maka tujuan terciptanya hasil pembelajaran yang baik akan sulit tercapai.

\section{Identifikasi Masalah}

Berdasarkan latar belakang masalah yang telah diuraikan diatas, maka dapat dipahami betapa pentingnya upaya peningkatan loyalitas kerja agar kinerja guru SD dapat menuai prestasi kerja . Dari uraian tersebut juga dapat dipahami bahwa banyak faktor yang dapat mempengaruhi meningkat atau menurunnya kinerja guru SD . Faktor-faktor yang dimaksudkan adalah:

1. Bagaimanakah tingkat motivasi kerja guru SD di Yayasan Pesantren Islam Al Azhar?

2. Adakah upaya-upaya yang dilakukan untuk mendorong kinerja guru SD ?

3. Bagaimanakah loyalitas kinerja guru SD di Yayasan Pesantren Islam Al Azhar?

4. Apakah ada pengaruh loyalitas terhadap kinerja guru SD ?

5. Apakah para guru telah memiliki sikap positif terhadap pekerjaannya?

6. Adakah pengaruh antara sikap guru terhadap hasil pekerjaannya ?

7. Apakah yang menyebabkan guru tidak mempunyai loyalitas dalam pekerjaannya ?

\section{Pembatasan Masalah}

Seperti yang telah diuraikan sebelumnya, faktorfaktor yang mempengaruhi peningkatan atau penurunan kinerja guru yang tidak mungkin dapat diamati secara keseluruhan. Padahal, dalam waktu yang sama, penulis memiliki sejumlah keterbatasan, terutama waktu, biaya, tenaga dan kemampuan akademik. Menyadari kondisi tersebut dan terutama sesuai dengan kaidah keilmuan, maka kajian penelitian ini hanya dibatasi pada satu hal yaitu :Pengaruh loyalitas terhadap kinerja guru SD. Selanjutnya untuk lebih memperdalam penelitian, maka dipilih dua variable yang relevan dengan permasalahan pokok, yaitu loyalitas sebagai variabel bebas (X), dan kinerja guru guru sebagai variabel terikat $(\mathrm{Y})$.

\section{Perumusan Masalah}

Perumusan masalah merupakan langkah yang paling penting dalam penelitian ilmiah. Perumusan masalah berguna untuk mengatasi kerancuan dalam pelaksanaan penelitian. Berdasarkan masalah yang dijadikan fokus penelitian, masalah pokok penelitian tersebut dirumuskan sebagai berikut: Apakah terdapat pengaruh loyalitas terhadap kinerja guru SD di SD Islam Al Azhar?

\section{Tujuan Penelitian}

Penelitian ini bertujuan untuk mengetahui pengaruh loyalitas terhadap kinerja guru SD di SD Islam Al Azhar.

\section{Kegunaan Penelitian}

Kegunaan/manfaat penelitian umumnya dipilah menjadi dua kategori, yaitu teoritis/akademis dan praktis/fragmatis. Kegunaan teoritis/akademis terkait dengan kontribusi tertentu dari penyelenggaraan penelitian terhadap perkembangan teori dan ilmu pengetahuan serta dunia akademis. Sedangkan kegunaan praktis/fragmatis berkaitan dengan kontribusi praktis yang diberikan dari penyelenggaraan penelitian terhadap obyek penelitian, baik individu, kelompok, maupun organisasi. Merujuk pada tujuan penelitian diatas, maka penelitian ini sekurang-kurangnya diharapkan dapat memberikan kegunaan yaitu dapat memberikan masukan yang berarti bagi guru SD di Yayasan Pesantren Islam Al Azhar dalam meningkatkan loyalitas kerja. khususnya melalui perspektif loyalitas. Sedangkan bagi semua pihak yang berminat untuk memperoleh informasi dan data dasar dalam mengadakan penelitian lanjutan yang berkaitan dengan penelitian ini, terutama mengenai faktor-faktor lain yang berpengaruh terhadap peningkatan kinerja guru. 


\section{TINJAUAN PUSTAKA}

\section{Kinerja Guru SD}

Melalui Kompetensi dan peranan guru tentu dapat diidentifikasi kinerja ideal seorang guru dalam melaksanakan peran dan tugasnya. Kinerja adalah performance atau unjuk kerja. Kinerja dapat pula diartikan prestasi kerja atau pelaksanaan kerja atau hasil unjuk kerja. Menurut Smith, Kinerja adalah performance is output derives from processes, human otherwise, artinya kinerja adalah hasil dari suatu proses yang dilakukan manusia. Dari pendapat di atas dapat dmaknai bahwa kinerja merupakan suatu wujud perilaku seseorang atau organisasi dengan orientasi prestasi. Kinerja seseorang dipengaruhi oleh beberapa faktor seperti: ability, capacity, held, incentive, environment dan validity [9]. Standar kinerja perlu dirumuskan untuk dijadikan acuan dalam mengadakan penilaian, yaitu membandingkan apa yang dicapai dengan apa yang diharapkan. Standar kinerja dapat dijadikan patokan dalam mengadakan pertanggungjawaban terhadap apa yang telah dilaksanakan.

Standar kinerja guru itu berhubungan dengan kualitas guru dalam menjalankan tugasnya seperti: (1) bekerja dengan siswa secara individual, (2) persiapan dan perencanaan pembelajaran, (3) pendayagunaan media pembelajaran, (4) melibatkan siswa dalam berbagai pengalaman belajar, dan (5) kepemimpinan yang aktif dari guru [4]. Kinerja guru mempunyai spesifikasi tertentu. Kinerja guru dapat dilihat dan diukur berdasarkan spesifikasi/kriteria kompetensi yang harus dimiliki oleh setiap guru. Berkaitan dengan kinerja guru, wujud perilaku yang dimaksud adalah kegiatan guru dalam proses pembelajaran yaitu bagaimana seorang guru merencanakan pembelajaran, melaksanakan kegiatan pembelajaran, dan menilai hasil belajar.

Kinerja (prestasi kerja) merupakan hasil kerja secara kualitas dan kuantitas yang dicapai oleh seorang pegawai dalam melaksanakan tugasnya sesuai dengan tanggung jawab yang diberikan kepadanya [1]. Sebagai hasil kerja secara kualitas dan kuantitas yang dicapai oleh seorang pegawai dalam melaksanakan tugasnya sesuai dengan tanggung jawab yang diberikan.

Seorang mempunyai empat fungsi umum yang merupakan ciri kinerja seorang guru, adalah sebagai berikut [2]: a. Merencanakan

Yaitu pekerjaan seorang guru menyusun tujuan belajar.

b. Mengorgasisasikan

Yaitu pekerjaan seorang guru untuk mengatur dan menghubungkan sumber-sumber belajar sehingga dapat mewujudkan tujuan belajar dengan cara yang paling efektif, efesien, dan ekonomis mungkin.

c. Memimpin

Yaitu pekerjaan seorang guru untuk memotivasikan, mendorong, dan menstimulasikan murid-muridnya, sehingga mereka siap mewujudkan tujuan belajar.

d. Mengawasi

Yaitu pekerjaan seorang guru untuk menentukan apakah fungsinya dalam mengorganisasikan dan memimpin di atas telah berhasil dalam mewujudkan tujuan yang telah dirumuskan. Jika tujuan belum dapat diwujudkan, maka guru harus menilai dan mengatur kembali situasinya dan bukunya mengubah tujuan.

Dengan demikian, penulis menyimpulkan dari pengertian di atas, bahwa kinerja adalah kemampuan seseorang untuk melaksanakan tugasnya yang menghasilkan hasil yang memuaskan, guna tercapainya tujuan organisasi kelompok dalam suatu unit kerja. Adapun indikator-indikatornya adalah sebagai berikut :

Berkenaan dengan kepentingan penilaian terhadap kinerja guru. Georgia Departemen of Education telah mengembangkan teacher performance assessment instrument yang kemudian dimodifikasi oleh Depdiknas menjadi Alat Penilaian Kemampuan Guru (APKG). Alat penilaian kemampuan guru, meliputi: (1) rencana pembelajaran (teaching plans and materials) atau disebut dengan RPP (Rencana Pelaksanaan Pembelajaran), (2) prosedur pembelajaran (classroom procedure), dan (3) hubungan antar pribadi (interpersonal skill).

Indikator penilaian terhadap kinerja guru dilakukan terhadap tiga kegiatan pembelajaran dikelas yaitu:

a. Perencanaan Program Kegiatan Pembelajaran

Tahap perencanaan dalam kegiatan pembelajaran adalah tahap yang berhubungan dengan kemampuan guru menguasai bahan ajar. Kemampuan guru dapat dilihat dari cara atau proses penyusunan program kegiatan pembelajaran yang dilakukan oleh guru, yaitu mengembangkan silabus dan rencana 
pelaksanaan pembelajaran (RPP). Unsur/komponen yang ada dalam silabus terdiri dari: (1). Identitas Silabus, (2). Stándar Kompetensi (SK), (3). Kompetensi Dasar (KD), (4). Materi Pembelajaran, (5). Kegiatan Pembelajaran, (6). Indikator, (7). Alokasi waktu, dan (8). Sumber pembelajaran.

Program pembelajaran jangka waktu singkat sering dikenal dengan sitilah RPP, yang merupakan penjabaran lebih rinci dan specifik dari silabus, ditandai oleh adanya komponenkomponen : (1). Identitas RPP, (2). Stándar Kompetensi (SK), (3). Kompetensi dasar (KD), (4). Indikator, (5).Tujuan pembelajaran, (6). Materi pembelajaran, (7). Metode pembelajaran, (8). Langkah-langkah kegiatan, (9). Sumber pembelajaran, dan (10). Penilaian

b. Pelaksanaan Kegiatan Pembelajaran

Kegiatan pembelajaran di kelas adalah inti penyelenggaraan pendidikan yang ditandai oleh adanya kegiatan pengelolaan kelas, penggunaan media dan sumber belajar, dan penggunaan metode serta strategi pembejaran. Semua tu-gas tersebut merupakan tugas dan tanggung jawab guru yang secara optimal dalam pelaksanaanya menuntut kemampuan guru.

Berdasarkan teori-teori yang telah dikemukakan di atas penulis dapat mengambil kesimpulan bahwa kinerja guru SD adalah kemampuan yang dihasilkan seorang guru dalam melaksanakan tugasnya sebagai pendidik dan pengajar sebagai guru SD yang memiliki keahlian mendidik anak dalam rangka pembinaan peserta didik untuk tercapainya tujuan pendidikan. Kinerja seseorang Guru akan nampak pada situasi dan kondisi kerja sehari-hari.

\section{Loyalitas}

Loyalitas adalah kemauan bekerja sama yang berarti kesediaan mengorbankan diri, kesediaan melakukan pengawasan diri dan kemauan untuk menonjolkan kepentingan diri sendiri. Kesediaan untuk mengorbankan diri ini melibatkan adanya kesadaran untuk mengabdikan diri kepada sebuah institusi [5]. Pengabdian ini akan selalu menyokong peran serta karyawan dalam institusi. Loyalitas kepada institusi sebagai sikap, yaitu sejauh mana seseorang karyawan mengidentifikasikan tempat kerjanya yang ditunjukan dengan keinginan untuk bekerja dan berusaha sebaik-baiknya dan kedua, loyalitas terhadap institusi sebagai perilaku, yaitu proses dimana seseorang karyawan mengambil keputusan pasti untuk tidak keluar dari institusi apabila tidak membuat kesalahan yang ekstrim [10].

Pengertian loyalitas sebagai keterikatan yaitu identifikasi psikologi individu pada pekerjaannya atau sejauh mana hubungan antara pekerjaan dan institusi tersebut dirasa sebagai total self image bagi dirinya dalam institusi, yang dapat disebut aktifitas-aktifitas masa lalu dalam institusi. Juga kesamaan tujuan antara individu dengan institusi. Pengalaman masa lalu dalam institusi akam mempengaruhi persepsi karyawan dalam pekerjaan dan institusi. Hal-hal yang terjadi terutama yang berhubungan dengan diri karyawan akan mempengaruhi persepsi karyawan terhadap perusakan. Demikian juga kesamaan tujuan antara karyawan dengan institusi akan sangat memberi nilai tersendiri terhadap keberadaanya di institusi tersebut.

Dalam kaitannya dengan pendidikan, seorang guru harus memenuhi dua kategori, yaitu memiliki kapabilitas dan loyalitas. Kapabilitas, yakni guru harus memiliki kemampuan dalam bidang ilmu yang diajarkannya, memiliki kemampuan teoritik tentang mengajar yang balk; mulai perencanaan, implementasi sampai evaluasi. Loyalitas keguruan, yakni loyal terhadap tugas-tugas keguruan, tidak semata di dalam kelas, tapi juga di luar kelas [7].

Betapapun bagusnya suatu kurikulum (official), tetapi hasilnya sangat tergantung pada apa yang dilakukan oleh guru dan juga siswa dalam kelas (actual) [6]. Bila dicermati kedua pernyataan tersebut di atas, maka keduanya menunjukkan bahwa berhasiltidaknya pelaksanaan kurikulum di sekolah sangat tergantung pada loyalitas guru.

Untuk itu seorang guru harus memiliki sifat: (1) menerima dan mematuhi norma, nilai-nilai kemanusiaan, (2) memikul tugas mendidik dengan bebas, berani dan gembira, (3) sadar akan nilainilai yang berkaitan dengan perbuatannya, (4) menghargai orang lain, (5) bijaksana dan hati-hati, dan (6) taqwa terhadap Tuhan Yang Maha Esa [9]. Seorang guru harus memiliki sepuluh kemampuan dasar sehingga dapat dikatakan profesional. Kemampuan dasar tersebut yaitu: (1) menguasai bahan pelajaran, (2) mengelola program belajar mengajar, (3) mengelola kelas, (4) menggunakan media/ sumber, (5) menguasai landasan-landasan kependidikan, (6) mengelola interaksi belajar mengajar, (7) menilai prestasi siswa untuk kepentingan pengajaran, (8) mengenal fungsi dan program pelayanan bimbingan dan penyuluhan, (9) mengenal dan menyelenggarakan administrasi 
sekolah, dan (10) memahami prinsip-prinsip dan menafsirkanhasil-hasil penelitian pendidikan guna keperluan pengajaran [8].

Loyalitas mencakup semua unsur, baik fisik maupun psikis. Sehingga dapat diketahui bahwa setiap tindakan dan tingkah laku seseorang merupakan cerminan dari kepribadian seseorang, selama hal tersebut dilakukan dengan penuh kesadaran. Setiap perkataan, tindakan, dan tingkah laku positif akan meningkatkan citra diri dan kepribadian seseorang. Begitu naik kepribadian seseorang maka akan naik pula wibawa orang tersebut.

Loyalitas akan turut menetukan apakah para guru dapat disebut sebagai pendidik yang baik atau sebaliknya, justru menjadi perusak anak didiknya. Sikap dan citra negative seorang guru dan berbagai penyebabnya seharusnya dihindari jauh-jauh agar tidak mencemarkan nama baik guru. Kini, nama baik guru sedang berada pada posisi yang tidak menguntungkan, terperosok jatuh. Para guru harus mencari jalan keluar atau solusi bagaimana cara meningkatnya kembali sehingga guru menjadi semakin wibawa, dan terasa sangat dibutuhkan anak didik dan masyarakat luas. Jangan sebaliknya.

Peran guru dinilai cukup strategis guna mengangkat harkat dan martabat rakyat agar tidak bodoh. Oleh sebab itu, guru diharapkan lebih mempertajam loyalitas pengabdiannya dibarengi niat ikhlas dalam mencerdaskan anak didik. Keteladan keseharian guru dalam segala aspek juga harus diutamakan. Tidak hanya di sekolah tapi juga di luar sekolah. Guru yang tetap idealis dan menjunjung moral sangat diharapkan. Pilihan profesi menjadi guru adalah pengabdian. Apabila pengabdian tersebut dapat diterapkan sepenuh hati, penghargaan masyarakat dan pemerintah akan datang dengan sendirinya.

Sangat penting seorang guru memiliki sikap yang mempunyai karakteristik pribadi sehingga dapat dibedakan ia dengan guru yang lain. Memang, kepribadian menurut Zakiah Darajat disebut sebagai sesuatu yang abstrak, sukar dilihat secara nyata, hanya dapat diketahui lewat penampilan, tindakan, dan atau ucapan ketika menghadapi suatu persoalan, atau melalui atasannya saja.

Guru sebagai teladan bagi murid-muridnya harus memiliki sikap dan kepribadian utuh yang dapat dijadikan tokoh panutan idola dalam seluruh segi kehidupannya. Karenanya guru harus selalu berusaha memilih dan melakukan perbuatan yang positif agar dapat mengangkat citra baik dan kewibawaannya, terutama di depan muridmuridnya. Disamping itu guru juga harus mengimplementasikan nilai-nilai tinggi terutama yang diambilkan dari ajaran agama, misalnya jujur dalam perbuatan dan perkataan, tidak munafik. Sekali saja guru didapati berbohong, apalagi langsung kepada muridnya, niscaya hal tersebut akan menghancurkan nama baik dan kewibawaan sang guru, yang pada gilirannya akan berakibat fatal dalam melanjutkan tugas proses belajar mengajar.

Guru yang demikian niscaya akan selalu memberikan pengarahan kepada anak didiknya untuk berjiwa baik juga. Hampir sulit ditemukan munculnya guru yang memiliki keinginan buruk terhadap muridnya. Dalam menggerakkan murid, guru juga dianggap sebagai partner yang siap melayani, membimbing dan mengarahkan murid, bukan sebaliknya justru menjerumuskannya. Mulyasa (2003: 151) menjelaskan bahwa komitmen secara mandiri perlu dibangun pada setiap individu warga sekolah termasuk guru, terutama untuk menghilangkan setting pemikiran dan budaya kekakuan birokrasi, seperti harus menunggu petunjuk atasan dengan mengubahnya menjadi pemikiran yang kreatif clan inovatif.

Untuk memantapkan budaya mutu dalam menuju sekolah unggul perlu dibangun komitmen menanamkan dalam diri personil sekolah untuk mencapai tujuan [11]. Hal ini menunjukkan bahwa komitmen merupakan suatu kesediaan untuk berpihak kepada sesuatu tugas yang didasari atas kreatifitas untuk mencapai suatu tujuan. Perasaan keberpihakan dan keterlibatan dalam tugas dapat diartikan sebagai unsur kebanggaan dan menyenangi sesuatu, rela berkorban dan bertanggung jawab.

Guru yang professional adalah guru yang siap untuk memberikan bimbingan nurani dan akhlak yang tinggi kepada muridnya. Karena pendidikan dana bimbingan yang diberikan bersumber dari ketulusan hati, maka guru benar-benar siap sebagai spiritual fatner bagi muridnya. Guru yang ideal sangat meresa gembira bersama dengan muridnya, ia selalu berinteraksi kepada muridnya, ia merasa senang karena dapat memberikan obat bagi muridnya yang sedang bersedih hati, murung, berkelahi, malas belajar. Guru professional akan selalu memikirkan bagaimana memacu 
perkembangan pribadi anak didiknya agar tidak mengalami kendala yang biasa mengganggu.

Kemuliaan hati seorang guru diwujudkan dalam kehidupan sehari-hari. Guru secara nyata dapat berbagi dengan anak didiknya. Guru tidak akan merasa lelah dan tidak mungkin mengembangkan sifat iri hati, munafik, suka menggunjing, menyuap, malas, marah-marah dan berlaku kasar terhadap orang lain, apalagi terhadap anak didiknya.

Berdasarkan uraian diatras dapat disimpulkan bahwa loyalitas kerja adalah suatu keadaan aktivitas yang menyangkut fisik, psikis dan sosial yang membuat individu mempunyai sikap untuk menaati peraturan yang ditentukan, melakukan dan mengamalkan sesuatu yang ditaatinya dengan penuh kesadaran dan tanggung jawab identifikasi personal terhadap upaya pencapaian tujuan institusi sesuai keahliannya sehingga peningkatan efektifitas institusi dan disertai dengan pengabdian yang kuat. Guru yakni loyal terhadap tugas-tugas keguruan, tidak semata di dalam kelas, tapi juga di luar kelas. Didukung komitmen guru yaitu suatu keberpihakkan diri terhadap suatu pekerjaan atau tugas atas dasar loyalitas, tanggung jawab, dan keterlibatan secara psikologis dalam tugas, seperti kebanggaan dan rela berkorban.

\section{Kerangka Berpikir}

\section{Pengaruh Loyalitas Kerja terhadap Kinerja Guru SD}

Setiap pekerjaan yang dilakukan seseorang selalu didorong oleh loyalitas yang kuat ada pada setiap manusia baik yang datang dari luar (ekstrinsik),maupun dorongan dari dalam. Hal ini dapat ditunjukan dalam hal standar pelayanan minimal ( SPM ) pada setiap Satuan Pendidikan kepada masyarakat dan khususnya pada peserta didik. Maksudnya, apabila variabel-variabel yang akan mempengaruhi loyalitas itu tidak dapat dipenuhi maka loyalitas pelayanan masyarakat khususnya layanan pendidikan akan sulit dibentuk. Layanan masyarakatsebagai landasan utama perlu dipelihara satuan Pendidikan. Untuk itu harus mampu memberikan pelayanan dan produk yang memuaskan pelanggan, sehingga dapat mendorong terciptanya pelanggan baru. Di samping pelanggan yang setia, pelanggan baru juga harus dapat dibina agar ingatan mereka tentang layanan dan produk yang dihasilkan institusi tetap ada. Eskalasi yang terjadi dalam menciptakan rasa memiliki dari pelanggan diikuti dengan tingkatan pembelian rata-rata pelanggan baru yang meningkat, serta frekuensi penjualan institusi menunjukkan peningkatan termasuk penjualan rata-rata yang juga meningkat. Hal yang demikian akan mempengaruhi organisasi institusi, karena sumber penerimaan ini dapat memenuhi kebutuhan biaya operasional organisasi, yang pada akhirnya dapat menutupi biaya gaji dan pelatihan pegawai, sekaligus akan menciptakan loyalitas pegawai pada organisasi.

Keberhasilan dan kegagalan seorang guru dalam menjalankan tugas yang dibebankan kepadanya ditentukan oleh adanya dorongan yang kuat dari guru tersebut. Guru yang melaksanakan tugas hanya karena adanya kekuatan yang datang dari luar dirinya akan menyebabkan penyelesaian pekerjaan yang semrawut.

Dengan demikian diduga bahwa terdapat pengaruh positif loyalitas terhadap kinerja guru. Dengan kata lain makin tinggi loyalitas seorang guru makin tinggi pula kinerjanya. Demikian pula sebaliknya makin rendah loyalitas yang dimiliki oleh seorang pegawai makin rendah pula kinerjanya.

\section{METODOLOGI PENELITIAN}

\section{Tempat dan Waktu Penelitian}

Penelitian ini dilakukan di SD Islam Al Azhar di Jakarta. Waktu pelaksanaan penelitian berlangsung 8 (delapan ) bulan.

\section{Metode Penelitian}

Berdasarkan rumusan masalah dan kerangka berfikir serta pengajuan hipotesis seperti yang termuat pada bab 2 , metode penelitian digunakan dalam penelitian untuk untuk mencapai tujuan yang diinginkan. Karena masalah yang diselidiki masalah yang baru, maka penulis menggunakan jenis penelitian deskriptif kuantitatif, yaitu penelitian yang menggunakan statistik dan banyak menggunakan logika hipotetika verifikatif. Pendekatan dimulai dengan berpikir deduktif untuk menurunkan hipotesis, kemudian melakukan pengujian di lapangan. Kesimpulan atau hipotesis ditarik berdasarkan data empiris.

Penelitian yang dilakukan penulis adalah penelitian lapangan secara studi kasus dengan menggunakan desain deskriptif dan kausal, yang memecahkan suatu kasus yaitu kasus mengenai 
hubungan loyalitas (variabel X) terhadap kinerja kerja guru SD, di mana $\mathrm{X}$ merupakan variabel bebas serta $\mathrm{Y}$ merupakan variabel terikat.

\section{Populasi dan Sampel}

Populasi target dalam penelitian ini adalah dari seluruh guru SD di Yayasan Pesantren Islam Al Azhar di Jakarta berjumlah 140 orang, sedangkan Populasi terjangkau dalam penelitian ini adalah seluruh guru SD di Yayasan Pesantren Islam Al Azhar yang ada di Jakarta yang berjumlah 42 orang. Teknik pengambilan sampel

Sampel dalam penelitian ini diambil menggunakan cara sampling acak sederhana.

\section{Metode Pengumpulan Data}

1. Variabel Penelitian

Variabel yang digunakan dalam penelitian ini terdiri atas 2 variabel, yaitu : 1) Variabel bebas $(\mathrm{X})$ : Loyalitas Kerja, b) Variabel terikat (Y): Kinerja Kerja Guru SD

\section{Sumber Data}

Dalam penelitian ini, ada tiga jenis data yang dikumpulkan berdasarkan sumbernya, yaitu :

a. Loyalitas kerja guru bersumber dari instrumen yang disebarkan kepada guru mata pelajaran SD yang menjadi sampel penelitian

b. Kinerja guru SD bersumber dari hasil instrumen yang disebarkan kepada guru mata pelajaran SD yang menjadi sampel penelitian dan literatur/dokumen yang dibutuhkan sesuai dengan penelitian.

\section{Teknik Pengumpulan Data}

\section{Pengumpulan Data Primer}

Variabel-variabel yang diteliti terdapat pada unit analisis yang bersangkutan dalam sampel penelitian. Data yang dikumpulkan dari setiap variabel ditentukan oleh definisi operasional variabel yang bersangkutan. Definisi operasional itu menunjuk pada dua hal yang penting dalam hubungannya dengan pengumpulan data, yaitu indikator empiris dan pengukuran.

Untuk mendapatkan data primer, digunakan instrumen pengumpulan data berupa kuesioner (angket). Kuesioner tersebut berisi beberapa pertanyaan mengenai indikator-indikator pengaruh loyalitas terhadap kinerja kerja guru SD di SD Islam Al Azhar Jakarta.

Jawaban menggunakan skala Likert 5 tingkat jawaban, yaitu jawaban 5 untuk skor Selalu, jawaban 4 untuk skor Sering, jawaban 3 untuk skor Kadang, jawaban 2 untuk skor Jarang dan jawaban 1 untuk skor Tidak Pernah. Pengumpulan data primer dilakukan melalui kegiatan penelitian lapangan (field research).

\section{Pengumpulan Data Sekunder}

Pengumpulan data sekunder dilakukan melalui kegiatan penelitian kepustakaan (library research) dengan cara mempelajari sumber-sumber bacaan/dokumen-dokumen penting, baik dari instansi maupun buku-buku bacaan manajemen.

Data tersebut diambil dari buku induk pegawai dan sumber-sumber lainnya yang memiliki validitas. Untuk data sekunder yang diambil dari buku-buku manajemen dan statistik mencakup dasar-dasar teori yang relevan dengan masalah yang diteliti, seperti teori-teori loyalitas kerja terhadap kinerja kerja guru SD. Teori-teori tersebut diambil dengan cara mengutip, baik secara langsung maupun tidak langsung.

\section{Variabel Penelitian}

Dalam penelitian ini terdapat tiga variabel yang diteliti yaitu variabel independen dan variabel dependen. Yang termasuk dalam variabel independen (variabel yang menyebabkan terjadi suatu hal atau variabel yang mempengaruhi) adalah loyalitas kerja sebagai variabel bebas; sedangkan yang termasuk dalam variabel dependen (terikat) atau variabel yang dipengaruhi, yaitu kinerja kerja guru SD .

Variabel-variabel yang diteliti terdapat pada unit analisis yang bersangkutan dalam sampel penelitian. Data yang dikumpulkan dari setiap variabel ditentukan oleh definisi operasional variabel yang bersangkutan. Definisi operasional itu menunjuk pada dua hal yang penting dalam hubungannya dengan pengumpulan data, yaitu indikator empiris dan pengukuran.

\section{Pengembangan Instrumen Penelitian}

Untuk memperoleh data empiris mengenai variabel yang diamati, dalam penelitian ini digunakan seperangkat instrumen berbentuk angket (kuesioner). Kuesioner digunakan untuk menghimpun informasi mengenai loyalitas dan kinerja guru SD.

\section{Instrumen Kinerja Guru SD (Y)}

\section{Definisi Konseptual}

Kinerja kerja guru SD adalah kinerja guru SD adalah pencapaian yang dihasilkan seorang guru dalam melaksanakan tugasnya sebagai pendidik 
dan pengajar sebagai guru SD yang memiliki keahlian mendidik anak dalam rangka pembinaan peserta didik untuk tercapainya tujuan pendidikan. Adapun indikator-indikator kinerja guru SD dapat dilihat dalam aspek kegiatan dalam menjalankan tugas dan cara/kualitas dalam melaksanakan kegiatan/tugas tersebut.

Indikator penilaian terhadap kinerja guru dilakukan terhadap tiga kegiatan pembelajaran di kelas yaitu: perencanaan program kegiatan pembelajaran, pelaksanaan kegiatan pembelajaran, evaluasi/penilaian pembelajaran

\section{Definisi Operasional}

Definisi operasional yaitu kinerja guru SD adalah kemampuan yang dihasilkan seorang guru dalam melaksanakan tugasnya sebagai pendidik dan pengajar sebagai guru SD yang memiliki keahlian mendidik anak dalam rangka pembinaan peserta didik untuk tercapainya tujuan pendidikan.

Kompetensi profesional guru SD adalah skor yang diperoleh melalui pemberian tes kepada guru SD yang berbentuk tes dan dapat diukur dari beberapa indikator.

\section{Validasi Instrumen}

Uji coba proses validasi dilakukan di salah satu SD di Yayasan Pesantren Islam Al Azhar dengan mengambil data dari 30 guru SD sebagai sampel.

\section{Validitas butir}

$$
r_{\text {hitung }}=\frac{n\left(\sum X Y\right)-\left(\sum X\right)\left(\sum Y\right)}{\sqrt{\left\{\sum X^{2}-\left(\sum X\right)^{2}\right\}-\left\{n \sum Y^{2}-\left(\sum Y\right)^{2}\right\}}}
$$

Dimana : $\mathrm{r}_{\text {hitung }}=$ koefisien korelasi, $\sum \mathrm{X}_{\mathrm{i}}=$ jumlah skor item, $\sum \mathrm{Y}_{\mathrm{i}}=$ jumlah skor total, $\mathrm{N}=$ jumlah responden

Kemudian $\mathrm{r}$ hitung dibandingkan dengan $\mathrm{r}$ tabel,

$$
r_{11}=\left(\frac{k}{k-1}\right)\left(1-\frac{\sum S i}{S t}\right)
$$

Dimana $\mathrm{r}_{11}=$ nilai reliabilitas, $\Sigma \mathrm{Si}=$ jumlah varian skor tiap tiap item, $\mathrm{St}=$ varians total, $\mathrm{k}=$ jumlah item.

Batas bawah koefisien Cronbach Alpha adalah 0,70 (Sugiyono, 2006), Kaidah keputusan : Jika $\mathrm{r}_{11}$ $>0,70 \rightarrow$ reliabel soal valid dan jika $\mathrm{r}_{11}<0,70$

$\rightarrow$ tidak reliabel soal tidak valid

\section{Instrumen Loyalitas Kerja (X) \\ Definisi Konseptual}

Loyalitas kerja guru SD adalah sikap setia dan perilaku patuh dalam menjaga dan memelihara organisasi agar tetap berjalan secara berkesinambungan sesuai tujuan organisasi, dengan indikator (1) berjanji setia, menjaga kesetiaan, memelihara organisasi, dan bangga pada sekolah, (2) berperilaku patuh, (3) sikap setia dan perilaku patuh berkelanjutan, (4) adanya keterbukaan, persepsi baik guru atas sekolah.

\section{Definisi Operasional}

Loyalitas guru SD adalah ungkapan sikap dan aktivitas guru. Untuk melihat sikap guru dalam melihat loyalitas guru SD yang ada pada diri guru yang pengukurannya dilakukan dengan angket, nilai atau skor yang diperoleh dengan menggunakan Skala Likert yang berbentuk skala dengan lima pilihan dan terdiri dari 30 butir pernyataan. Skor loyalitas guru diperoleh dari jumlah skor 30 butir pernyataan dengan rentang skor terletak antara 30 sampai 150.

\section{Validasi Instrumen}

Uji coba proses validasi dilakukan di salah satu SD di Yayasan Pesantren Islam Al Azhar dengan mengambil data dari 30 guru SD sebagai sampel.

$$
r_{\text {hitung }}=\frac{n\left(\sum X Y\right)-\left(\sum X\right)\left(\sum Y\right)}{\sqrt{\left\{n \sum X^{2}-\left(\sum X\right)^{2}\right\}-\left\{n \sum Y^{2}-\left(\sum Y\right)^{2}\right\}}}
$$

Dimana :

$\mathrm{r}_{\text {hitung }}=$ koefisien korelasi, $\sum \mathrm{X}_{\mathrm{i}}=$ jumlah skor item, $\sum \mathrm{Y}_{\mathrm{i}} \quad=$ jumlah skor total, $\mathrm{n}=$ jumlah responden

Kemudian $r$ hitung dibandingkan dengan $r$ tabel.

$$
r_{11}=\left(\frac{k}{k-1}\right)\left(1-\frac{\sum S i}{S t}\right)
$$

Dimana : $\mathrm{r}_{11}=$ nilai reliabilitas, $\Sigma \mathrm{Si}=$ jumlah varian skor tiap-tiap item, $\mathrm{St}=$ varians total, $\mathrm{k}=$ jumlah item

Batas bawah koefisien Cronbach Alpha adalah 0,70 (Sugiyono, 2006) dengan kaidah keputusan : Jika $\mathrm{r}_{11}>0,70 \rightarrow$ reliabel soal valid, dan jika $\mathrm{r}_{11}$ $<0,70 \rightarrow$ tidak reliabel soal tidak valid.

\section{Teknik Analisis Data}

Analisis Deskriptif dan Inferensial

Dalam analisis deskriptif akan dilakukan teknik penyajian data dalam bentuk tabel distribusi 
frekuensi, grafik poligon dan histogram untuk masing-masing variabel penelitian. Selain itu juga masing-masing kelompok data akan diolah dan dianalisis ukuran pemusatan dan letak seperti mean, modus, dan median serta ukuran simpangan seperti jangkauan, variansi, simpangan baku, kemencengan dan kurtosis. Proses pengolahan untuk menguji analisis deskriptif tersebut dilakukan dengan menggunakan program SPSS 22.0 .

Data yang diperoleh dari hasil penelitian dianalisis dengan menggunakan analisis statistik deskriptif dan analisis statistik regresi. Analisis statistik deskriptif dilakukan dengan mendeskripsikan semua data dari semua variabel dalam bentuk; distribusi frekuensi, histogram, modus, median, harga rata-rata serta simpangan baku (standar deviasi). Sedangkan analisis statistik regresi dilakukan untuk menguji pengaruh hipotesis yang telah dirumuskan. Sebelumnya terlebih dahulu dilakukan pengujian persyaratan analisis yaitu uji normalitas dan uji homogenitas.

\section{Uji Persyaratan Analisis Data}

Uji persyaratan analisis data dimaksudkan untuk mengetahui apakah data yang telah dikumpulkan layak untuk dianalisis lebih lanjut menggunakan alat-alat statistik. Pengujian yang dilakukan adalah pengujian normalitas data, pengujian linieritas, dan pengujian multikolinieritas yang secara keseluruhan dibantu oleh program komputer SPSS 22.0. Adapun kriteria pengujian untuk normalitas adalah: jika nilai sig $>0,05$; maka data berdistribusi normal dan jika nilai sig < 0,05 ; maka data tidak beridistribusi normal.

Sementara itu kriteria pengujian linieritas adalah jika Fhitung < Ftabel atau nilai sig < 0,05; maka persamaan regresi linier. Jika Fhitung < Ftabel atau nilai sig $>0,05$; maka persamaan regresinya tidak linier. Dan uji multikolonieritas dapat dilihat dari besarnya VIF (varians inflation factor) dan tolerance. Pedoman suatu model regresi yang bebas multikolinieritas adalah yang mempunyai nilai VIF di sekitar angka 1 dan memiliki toleransi mendekati 1.

\section{Uji Hipotesis Penelitian}

Setelah keseluruhan uji persyaratan analisis data dipenuhi dan diketahui data layak untuk diolah lebih lanjut, maka langkah berikutnya adalah menguji masing-masing hipotesis yang telah diajukan. Pengujian hipotesis menggunakan regresi ganda. Data yang diperoleh diolah dengan menggunakan SPSS 22.0 dan menggunakan cara manual.

Pengujian statistik menggunakan hipotesis nol dan hipotesis alternatif sebagai berikut:

$\mathrm{H}_{0}: \rho_{1}=0 \rightarrow$ tidak ada pengaruh antara loyalitas kerja terhadap kinerja kerja guru SD .

$\mathrm{H}_{1}: \rho_{1} \neq 0 \rightarrow$ ada pengaruh antara loyalitas kerja terhadap kinerja kerja guru SD .

Keterangan: $\rho_{1}=$ Koefisien pengaruh variabel loyalitas kerja terhadap kinerja kerja guru SD .

\section{HASIL DAN PEMBAHASAN}

\section{Deskripsi Data \\ Kinerja guru (Y)}

Kinerja guru dapat dilihat dalam aspek kegiatan dalam menjalankan tugas dan cara/kualitas dalam melaksanakan kegiatan/tugas tersebut. Data Kinerja guru diperoleh dari hasil test yang terdiri dari 30 butir pernyataan yang dijawab oleh 42 orang responden. Nilai yang diperoleh adalah skor terendah 47, skor tertinggi 97, skor ratarata sebesar 74,86, median sebesar 77 , modus sebesar 77 dan simpangan baku sebesar 12,25.

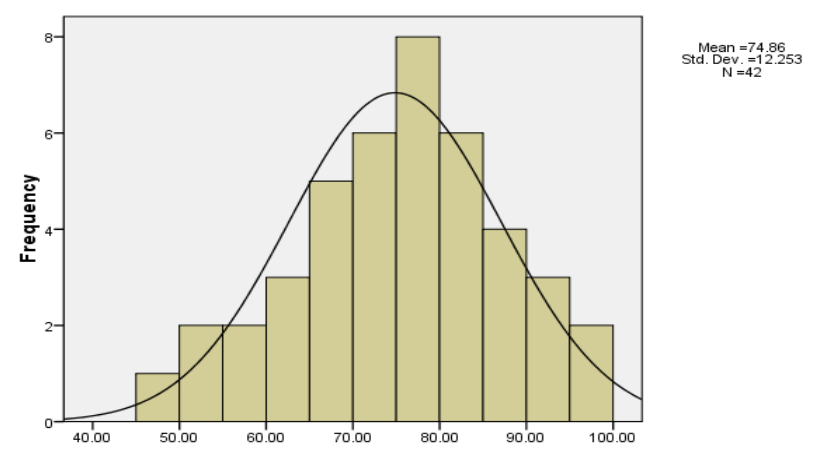

Gambar 1. Poligon Histogram Distribusi Variabel Y

Bila dilihat dari hasil perhitungan dan diagram di atas, maka bisa dikatakan bahwa kinerja guru Yayasan Pesantren Islam Al Azhar berdistribusi yang normal.

\section{Loyalitas Guru $\left(\mathbf{X}_{1}\right)$}

Data loyalitas guru diperoleh dari kuisioner yang terdiri dari 30 pernyataan yang dijawab oleh 42 orang responden dihasilkan skor terendah 40, skor tertinggi 95, skor rerata sebesar 68,42; median sebesar 70; modus sebesar 70, dan simpangan baku sebesar 12,99. Untuk memperjelas data di atas, digambarkan dalam histogram sebagai berikut: 


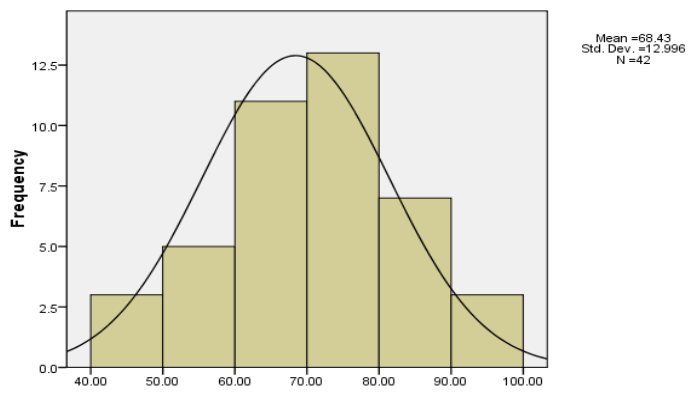

Gambar 2. Poligon Histogram Distribusi Variabel $\mathrm{X}_{1}$

Dari hasil perhitungan dan diagram di atas, maka bisa dikatakan bahwa loyalitas guru guru SD Yayasan Pesantren Islam Al Azharsangat baik. Hal ini diindikasikan dengan gambar distribusi yang normal.

\section{Pengujian Persyaratan Analisis}

\section{Uji Normalitas Kinerja guru}
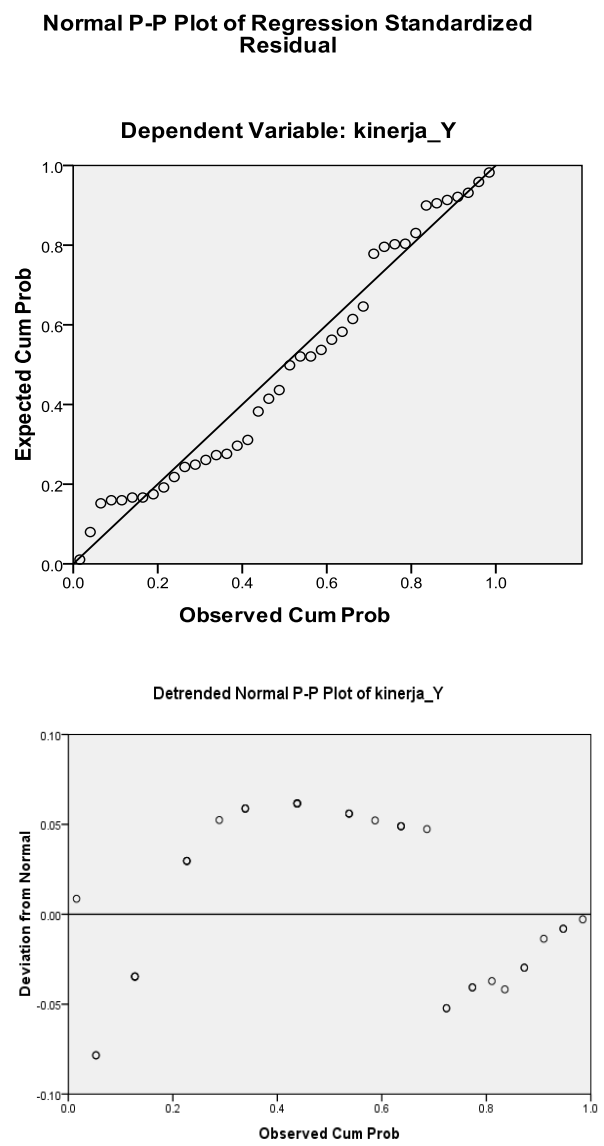

Gambar 3. Scater plot Normalitas Instrumen Kinerja

Persyaratan dalam menganalisis data yang pertama dilakukan adalah uji normalitas, uji ini dilakukan untuk mengetahui normal tidaknya distribusi data yang akan dianalis dan dilakukan dengan menggunakan perhitungan SPSS 22.0 dengan jumlah sampel sebanyak 42 .

Menurut ketentuan yang ada data berdistribusi normal apabila titik-titik pada gambar mendekati garis kenormalan, sedangkan pada gambar detrended, suatu data dikatakan normal apabila titik-titik pada gambar semakin tidak membentuk gambar (menjauhi garis kenormalan). Dengan menggunakan Analisis Kolmogorov Smirnov dalam SPSS 15.0. Distribusi data dikatakan normal jika nilai sig $>0,05$.

\section{Uji Normalitas Loyalitas Guru}

$$
\begin{gathered}
\text { Normal P-P Plot of Regression Standardized } \\
\text { Residual }
\end{gathered}
$$
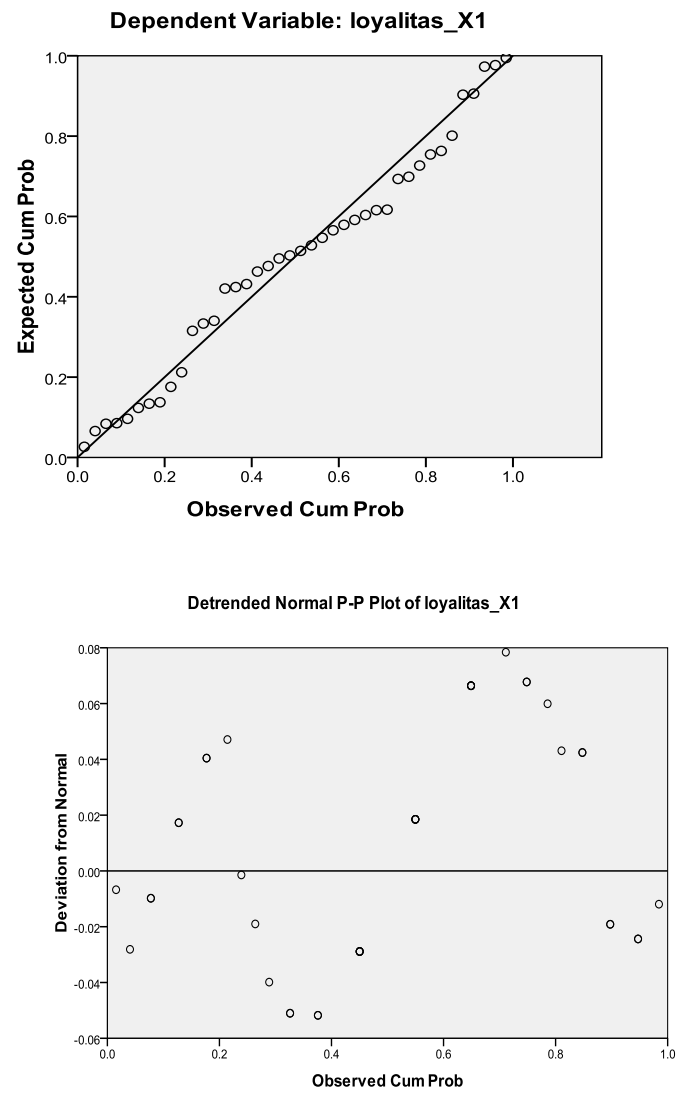

Gambar 4. Scater plot Instrumen Loyalitas Kerja

Menurut ketentuan yang ada data berdistribusi normal apabila titik-titik pada gambar mendekati garis kenormalan, sedangkan pada gambar detrended, suatu data dikatakan normal apabila titik-titik pada gambar semakin tidak membentuk gambar (menjauhi garis kenormalan).

\section{Uji Linearitas}

Uji linearitas dilakukan untuk menentukan teknik dalam analisis regresi apakah variabel bebas $\left(\mathrm{X}_{1}\right)$ dan variabel terikat (Y) terbentuk linear. Uji 
linearitas ini menggunakan pehitungan SPSS 22.0. Pengujian linieritas garis regresi dalam penelitian ini menggunakan pendekatan atau analisis tabel Anova dari nilai statistik F untuk tuna cocok dan nilai koefisien signifikansi (Sig.) yang diperoleh dari penelitian.

Berdasarkan hasil pengolahan dengan SPSS (Anova tabel kolom $\mathrm{F}$ dan koefisien signifikansi pada baris Deviation from Linierity) diperoleh hasil:Variabel $\mathrm{Y}$ atas $\mathrm{X}_{1}$ diperoleh $\mathrm{F}_{\text {hitung }}=0,969$ dan $\mathrm{F}_{\text {tabel }}(\mathrm{dk}=41)=1,56$; karena $\mathrm{F}_{\text {hitung }}<\mathrm{F}_{\text {tabel }}$ atau $(0,969<1,56)$, maka Ho diterima, artinya regresi linier atau karena Sig 0,536 >0,05, maka Ho diterima, artinya regresi linier.

Tabel 1. Hasil Uji Linieritas Loyalitas Guru $\left(\mathrm{X}_{1}\right)$ Terhadap Kinerja guru (Y)

ANOVA Table ${ }^{\mathrm{a}}$

\begin{tabular}{|c|c|c|c|c|c|c|c|}
\hline & & & $\begin{array}{l}\text { Sum of } \\
\text { Squares }\end{array}$ & df & $\begin{array}{l}\text { Mean } \\
\text { Square }\end{array}$ & $\mathrm{F}$ & Sig. \\
\hline & \multirow{4}{*}{$\begin{array}{l}\text { Between } \\
\text { Groups }\end{array}$} & (Combined) & 1087,587 & 43 & 25,293 & 1,026 & 454 \\
\hline $\mathrm{Y}$ & & Linearity & 84,671 & 1 & 84,671 & 3,435 &, 068 \\
\hline$*$ & & Deviation & & & & & \\
\hline \multirow[t]{2}{*}{$\mathrm{X} 1$} & & $\begin{array}{l}\text { from } \\
\text { Linearity }\end{array}$ & 1002,916 & 42 & 23,879 & ,969 &, 536 \\
\hline & \multicolumn{2}{|c|}{ Within Groups } & 1774,990 & 72 & 24,653 & & \\
\hline
\end{tabular}

\subsection{Pengujian Hipotesis}

Tabel 2. Hasil Uji Hipotesis loyalitas guru $\left(\mathrm{X}_{1}\right)$ terhadap kinerja guru (Y)

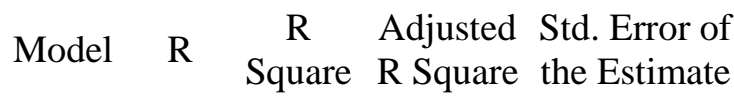

\begin{tabular}{rrrrr}
\hline 1 & $.965^{\mathrm{a}}$ & .932 & .930 & 323444 \\
\hline \multicolumn{4}{c}{ Model Summary }
\end{tabular}

Koefesien korelasi $\left(\mathrm{r}_{\mathrm{yl}}\right)$ sebesar 0,965 lebih besar dari $\mathrm{r}_{\text {tabel }}$ sebesar 0,304 mempunyai makna bahwa pengaruh antara loyalitas guru terhadap kinerja guru sangat kuat. Sementara itu, koefisien determinasi $\left(\mathrm{r}_{\mathrm{y}}^{2} 1\right)$ sebesar $=$ 0,932 mempunyai makna bahwa $93,2 \%$ yang terjadi dalam kecenderungan besarnya pengaruh meningkatnya loyalitas guru $\left(\mathrm{X}_{1}\right)$ terhadap kinerja guru. Hasil analisis pada tabel 2 bahwa loyalitas guru menunjukkan nilai $\mathrm{t}$ hitung $=0,349$ selanjutnya diperoleh nilai ttabel untuk signifikansi $5 \%=1,64$.
Hasil $t_{\text {hitung }}$ sebesar 0,349 lebih kecil dari $t_{\text {tabel }}=1,64$. Dengan demikian $\mathrm{H}_{1}$ ditolak dan $\mathrm{H}_{0}$ diterima, maka keadaan ini menyatakan tingkat signifikansi pengaruh antara variabel loyalitas guru terhadap kinerja guru sangat lemah.

Berdasarkan hasil analisis data SPSS versi 22.0 dapat diketahui bahwa loyalitas guru memiliki pengaruh terhadap kinerja guru yang ditandai dengan perolehan koefesien korelasi $\left(\mathrm{r}_{\mathrm{yl}}\right)$ sebesar 0,965 lebih besar dari $\mathrm{r}_{\text {tabel }}$ sebesar 0, 304 mempunyai makna bahwa pengaruh antara loyalitas guru dengan kinerja guru sangat kuat. Sementara itu hasil koefisien determinasi $\left(r_{y}^{2} 1\right)$ sebesar $=0,932$ mempunyai makna bahwa 93,2 \% yang terjadi dalam kecenderungan besarnya pengaruh meningkatnya loyalitas guru $\left(\mathrm{X}_{1}\right)$ terhadap Kinerja guru Sisanya 6,8\% dijelaskan oleh sebab-sebab lain. Dari data tersebut di atas, dapat dikatakan bahwa apabila kinerja guru ingin ditingkatkan secara optimal, maka perlu peningkatan loyalitas guru yang tinggi. Pemberian loyalitas guru yang baik akan memberikan dorongan bagi guru untuk meningkatkan kinerjanya.

Berdasarkan hasil perhitungan di atas, maka hasil penelitian ini sejalan dengan pengajuan hipotesis , yaitu bahwa loyalitas guru memberikan pengaruh positif terhadap kinerja guru.

\section{KESIMPULAN}

\section{Kesimpulan}

Berdasarkan analisis data, pembuktian hipotesis penelitian dan pembahasan hasil penelitian, maka penelitian tentang pengaruh loyalitas guru terhadap kinerja guru SD Awal dapat disimpulkan: Loyalitas guru berpengaruh terhadap kinerja guru yang ditandai dengan perolehan koefisien determinasi $\left(\mathrm{r}_{\mathrm{yl}}^{2}\right)$ sebesar $=0,932$ Hal ini berarti bahwa 93,2\% loyalitas guru $\left(\mathrm{X}_{1}\right)$ berpengaruh terhadap kinerja guru dan 6,8\% ditentukan oleh faktor lain. Hasil analisis menunjukkan nilai $\mathrm{t}$ hitung $=0,349$ selanjutnya diperoleh nilai $t_{\text {tabel }}$ untuk signifikansi $5 \%$ dengan derajat kebebasan $\quad 40-2=38$ diperoleh nilai $\mathrm{t}$ tabel $=1,64$. Hasil $\mathrm{t}_{\text {hitung }}$ sebesar 0,349 lebih kecil dari $t_{\text {tabel }}=1,64$. Dengan demikian $\mathrm{H}_{1}$ ditolak dan $\mathrm{H}_{0}$ diterima. Hal ini berarti variabel loyalitas guru berpengaruh tidak signifikan terhadap kinerja guru .

\section{Saran}

Berdasarkan hasil penelitian, kesimpulan di atas yang menggambarkan pengaruh loyalitas terhadap 
kinerja guru sangat kuat, maka dapat dirumuskan beberapa saran dengan penekanan pada:

a. Kinerja guru adalah kemampuan yang dihasilkan seorang guru dalam melaksanakan tugasnya sebagai pendidik dan pengajar sebagai guru yang memiliki keahlian mendidik anak dalam rangka pembinaan peserta didik untuk tercapainya tujuan pendidikan, maka guru harus terus meningkatkan kinerja guru dikelas berupa melakukan perencanaan program kegiatan pembelajaran, pelaksanaan kegiatan pembelajaran dan melakukan evaluasi/penlaian pembelajaran.

b. Untuk meningkatkan loyalitas kerja guru, maka guru dituntut harus mempunyai sikap untuk mentaati peraturan yang ditentukan, melakukan dan mengamalkan sesuatu yang ditaatinya dengan penuh kesadaran dan tanggungjawab identifikasi personal terhadap pencapaian tujuan institusi sesuai keahliannya.

\section{DAFTAR PUSTAKA}

[1] Anwar Prabu Mangkunegara, Manajemen Sumber Daya Manusia Perusahaan, Remaja Rosdakarya, Bandung,p. 58, 2001.

[2] Davis, Keith dan Newstrom, Perilaku Dalam Organisasi, Edisi ketujuh, Penerbit Erlangga, Jakarta, p. 78, 2000.
[3] Djamarah, Zain, Strategi Belajar Mengajar, Rineka Cipta, Jakarta, p.36, 2006.

[4] Kusmianto, Panduan Penilain Kinerja Guru oleh Pengawas, Diknas, Jakarta, p.49, 1997.

[5] Muhyadi, Organisasi, Teori, Struktur dan Proses, LPTK, Depdikbud, Jakarta, p.251, 1989.

[6] Mulyasa, E, Manajemen Berbasis Kompetensi dan Aplikasinya, Rosdakarya, Bandung, p.147, 2003.

[7] Nurdin, Syafruddin, Guru Profesional dan Implementasi Kurikulum, Quantum Teaching, Jakarta, p.178, 2005.

[8] Sardiman, A.M., 1994, Interaksi dan Motivasi Belajar Mengajar, p. 163, Bandung, Rajawali Press.

[9] Soekinjo. DR., Notoatmodjo, Pengembangan Sumber Daya Manusia, Rineka Cipta, Jakarta p.25, 1992

[10] Steers R. M dan Porter L. W, Motivation and Leadership at Work, New York, McGraw Hill, p. 47, 1987.

[11] Syafaruddin dan Irwan Nasution, Manajemen Pembelajaran, Quantum Teaching, Jakarta, p. 154, 2005. 